\title{
From Cyber Bullying to Cyber Coping: The Misuse of Mobile Technology and Social Media and Their Effects on People's Lives
}

\author{
Eddie Fisher (Corresponding author) \\ Faculty of Social Sciences, Universidad de Oriente, Santiago de Cuba, Cuba \\ Univerzita Palackeho, Olomouc, Czech Republic, 8 Kendal, Swindon, \\ Wiltshire, SN5 8HW, United Kingdom
}

Tel: 44-179-349-0423 E-mail: eddie.fisher9@btInternet.com

Received: August 27, 2013 Accepted: September 17, 2013

doi:10.5296/ber.v3i2.4176 URL: http://dx.doi.org/10.5296/ber.v3i2.4176

\begin{abstract}
The ability to deal and cope with cyber bullying attacks is becoming increasingly important to children and young people in the United Kingdom although this phenomenon appears to be acute in many other countries, too. This paper investigates and provides a deeper understanding of what the effects of cyber bullying have on people's lives. The results show that there is a relationship between an increase in access to digital technology and the methods cyber bullies apply to threaten, harass, humiliate and embarrass people. Results suggest that parents, teachers, employers and owners of social media sites are not educating and coaching young people sufficiently so that these can stay safe in a world of texting, twittering and social networking. The research suggests a number of practical solutions such as incentivized schemes and engaging young people in cyber bullying awareness focus groups. It is anticipated that this will help young people to develop their own levels of responsibilities to make informed decisions what is safe for them to access, view and act upon.
\end{abstract}

Keywords: Cyber bullying, Mobile phone technology, E-Safety, Social networks, Attitude and behavior

\section{Introduction}

\subsection{Introduction}

It appears that the misuse of mobile technology and social media networks is becoming 
epidemic not just in the United Kingdom but also in other countries such as the United States. A few years ago words such as "cyber bullying" or "e-safety" would not have meant much to most people. Today these words appear to have become part of people's everyday vocabulary. The meaning of these words is clear to most people but not everyone understands what the consequences are to people's lives who are, for example, cyber bullied. According to Giant (2013) the explosion of twentieth-century technology has been unprecedented and most people cannot remember a time when this technology did not exist. Mobile technology allows people to communicate with each other at any time anywhere in the world. It is possible to send pictures and video clips to friends and family at the click of a button. This revolution has changed people's lives irreversibly. The vast majority of children and young people own a computer and mobile phone which gives them unlimited access to information and allows them to share this information with others across the globe (Rogers, 2010). Older people perhaps have developed a sense of caution not to trust technology blindly. In contrast, younger people do not have this balanced view. They were born and are brought up in a world that is full of technology that forms a substantial part of their everyday lives. It appears that the technology has become a right to most young people. This explains why the technology is used extensively throughout their daily lives, exceeding the uses of most adults by a substantial margin. With the right to have and use this technology also come responsibilities such as how to use the technology responsibly and in such a way that no direct or indirect harm is caused to other people. This is the theory but reality looks different. Access to the new technology has led to an increase in misuse or abuse of this technology leading to many incidents of threatening, harassing, embarrassing and humiliating behaviors and actions. Cases of so-called cyber bullying have become proportionately sophisticated as access to the new technology has grown. Predators can target their selected audience quite easily and with hardly any effort and at very low cost if any. The misuse of mobile technology and social media has become a concern of parents, social psychologists and authorities including schools, colleges and universities. The aim and objectives of this research are to investigate the current status of the misuse of mobile technology and social media in the UK and some other countries. The research will suggest practical mitigations to try and help young people to move from cyber bullying to cyber coping (Figure1). The article further aims to promote the responsibilities of safe and acceptable use of these and to mitigate the risks of misuse whether at work, in schools or at home, and the role social psychology needs to play to achieve the desired outcomes.
Cyber Bullying
Social Psychology
Cyber Coping

\begin{tabular}{|c|c|c|}
\hline Threaten & Educate & Being in Control \\
\hline Harass & Self-Confidence & Shrug off Attacks \\
\hline Humiliate/Denigrate & Attitude/Behavior & ICT Astute \\
\hline Embarrass & Real/Cyber Worlds & Respect for Others \\
\hline Blackmail & Online Protocols & Face to Face Comms \\
\hline Flaming/Exclusion & Influencing/Persuasion & Know who to Trust \\
\hline
\end{tabular}

Figure 1 From Cyber Bullying to Cyber Coping 


\subsection{Literature Review}

\subsubsection{Misuse of Mobile Technology and Cyber Bullying}

According to some recent research by Giant (2013), it is difficult for people to conceptualize what the Internet and related technologies actually represent. It is therefore more difficult for people to rely on their intuitions and common sense to navigate through the maze of technology. Common sense usually develops a degree of maturity and a sense of individual responsibility. A moral appreciation of right and wrong also falls into this category. These qualities are generally linked to age and children/young people are not expected to hold the same degree of maturity, responsibility and moral values as the adults around them. Experience does matter in this context. With so many people having access to the Internet and associated mobile technologies, it is perhaps too late to pretend that this technology does not exist. The time has come to make explicit not just the benefits of the new technology but also the risks associated with it. This should also include the related responsibilities to keep everyone safe and ensure people's well-being in both the real and the "virtual" world. Giant suggests that the issue of cyber bullying is only as old as the technologies used to hurt and denigrate others. The research and study of cyber bullying is still growing but perhaps not as fast as the phenomenon itself. Giant quotes Belsey (2004, p.1) who defines cyber bullying as a phenomenon that ".....involves the use of information and communication technologies to support deliberate, repeated and hostile behavior by an individual or group that is intended to harm others". Giant points out further that any technology can be used for both positive and negative effects but the extremes to which mobile phones, online platforms and other forms of technology are abused to bully others, often leaves,for example, parents, youths and teachers astounded.

Giant suggests that there are seven forms of cyber bullying:

1. Flaming: sending angry, rude, vulgar messages directed at a person or persons privately or to an online group

2. Harassment: repeatedly sending a person offensive messages

3. Denigration: sending/posting rumors, harmful, untrue information about a person to others

4. Cyber stalking: harassment that includes threats of harm or is highly intimidating

5. Impersonation or masquerading: to be another person and posting/sending material online to make them look bad

6. Outing or trickery: tricking a person into sending information (secrets, embarrassing information) that can be used to send to others online

7. Exclusion: excluding someone purposefully from an online group, for example, an IM or BBM list

Source: Willard (2007) 
Giant (p.23) considers that "It is widely understood that face to face communication is conducted not only through the spoken word but through tone, intonation, body language and other non-verbal cues that alert participants to potential discrepancies, incongruencies or dangers. Virtual communication often asks participants to make a judgment about the content by relying solely upon the words with which they are presented. This can be particularly difficult for children and young people with less maturity, awareness of risk and connection with their intuition or an inner sense of right and wrong". Different types of technology such as text and instant messaging, E-mail and online chat rooms are often used as a method of harassment, discrimination and bullying of others. Giant considers that some form of harassment or cyber bullying maybe deemed to be a criminal offence as far as adults are concerned. This consideration is particularly relevant in the context of this research as many cyber bullying offences are committed by those who are over 18 years of age. Giant suggests that there is a difference in opinion among researchers whether cyber bullying is a phenomenon that is perpetrated by and affects more girls than boys. Both sexes are using the technology and can, therefore, also experience cyber bullying, and both could be just as likely to commit it. It appears that girls are more likely to be involved in cyber bullying.

According to Lenhart (2007) and Smith et al (2008), this is perhaps due to the increased likelihood of girls utilizing relationally aggressive tactics which can be suitably employed online. This includes isolation, rumor and gossip spreading and otherwise damaging and manipulating relationships to gain power and control. Hinduja and Patchin (2009) found that girls engaged in cyber bullying for longer than boys, and employed different tactics, including taking pictures of victims and posting them online.

The Kaiser Foundation in the United States (2010) reports that young people 8-18 years old spend more than seven and a half hours each day using some form of media or technology, including TV, games consoles or a computer. This does not include the 90 minutes or so each day that young people spend texting or talking on the phone. Except time spent sleeping or at school, this means that young people spend every possible moment using some form of technology. This raises the possibilities and potential for bullying, access to inappropriate content, unsafe conduct and general health and social risks related to technological over-use.

The Pew Research Centre (2010) in the United States found that $3 / 4$ of teens now have a mobile phone, with as many as 58\% of 12-year olds owning a phone, up from just $18 \%$ of such teens as recent as 2004. Researchers found that $93 \%$ of both teens and adults aged 12-29 years of age go online, compared to only $74 \%$ of all adults. A study conducted by the international consumer research specialist Intersperience (2012) declared that $65 \%$ of the approximate 32 million Smartphone users in the United Kingdom would declare themselves to be "lost" without their phone. An Ofcom (2011) report that specifically studied the use of technology, suggests that $81 \%$ of Smartphone users have their phones switched on all of the time, even when they are in bed, with $40 \%$ of teens admitting to using their Smartphone after it woke them. An earlier study conducted by Ofcom (2010) found that young people between 5-15 years of age:

1. Only $1 \%$ of $12-15$ year olds in the United Kingdom do not have access to the Internet at home 
2. Half of 5-7 year olds (49\%), 2/3 of 8 -11year olds $(67 \%)$ and $3 / 4$ of $12-15$ year olds $(77 \%)$ have a TV in their bedroom

3. $85 \%$ of parents trust their children to use the Internet safely

4. Only $34 \%$ of parents whose children are aged $12-15$, are likely to be concerned about Internet content

A study conducted by Carnegie Mellon University concluded that Internet use leads to small but statistically significant increases in misery and loneliness and a decline in overall psychological well-being (De Angelis, 2000). With this increasing use of the Internet and related technologies in children as young as two years old, there is a debate among psychologists as to the prevalence of a psychological disorder associated with online use. Labeled by some as Internet Addiction Disorder (Goldberg, 1996), studies suggest that the growth of addictive behavior is typical among heavy Internet users (Greenfield, 1999; Young, 1998).

"The web filtering standard set by Becta (2012, p.1) should be considered as the technical minimum threshold for safe Internet access for children and staff in education as no other implementable standard currently exists". Becta sets an accreditation standard for filtering products or services, including a need for the product or service to block $100 \%$ of illegal material identified by the Internet Watch Foundation (CAIC) List. The software should be able to block approximately $90 \%$ of inappropriate Internet content in categories such as violence, race hate material, illegal drug taking and criminal skill/activity.

From June 2012, Ofsted (2012), the UK school inspection authority, will feature e-safety and cyber bullying as part of school inspection criteria. The aim is to ensure that students not only feel safe at school but also understand how to keep themselves and others safe.

Rogers (2010) suggests that mobile technology and access to social networks gives young people almost unlimited access to information. This positive side is overshadowed by a darker side. The misuse of technology to threaten, harass, humiliate and embarrass victims is defined as "cyber bullying". Particularly young people are affected by this approach of psychological attacks.

Rogers considers that cyber bullying is just as unacceptable as physical bullying, leaving emotional rather than physical scars. The emotional damage is not tangible so victims are often left with a feeling that there is no safe place to escape to and that they cannot trust anyone anymore. Young people need to be encouraged and made feel comfortable to talk about how they use the Internet and their mobile phones. Victims need the language to be able to express what has happened to them, to know that it is wrong and to be able to tell someone they can trust. This is now of widespread concern how children and young people can stay safe in a texting, twittering and social networking world. Rogers considers that cyber bullying is different from ordinary bullying in a number of ways. The bullies can keep a safe distance between themselves and their victims. They maintain anonymity. There are no feelings of guilt or empathy. Cyber bullying can take place 24 hours a day, seven days a week. Table 1 is a summary of the most common used cyber bullying methods. Rogers suggests that it is also 
important for parents to encourage young people to keep detailed records of any offending material or communication, as this could be used later on in court or by some service providers to make their sites/services safer. It is important to guide young people to deal with "real world" issues in the "real world" and not to get side-tracked into cyber land. Young people should accept only friends from the real world as friends on social networks such as My Space and Twitter. Rogers suggests that parents should be particularly aware of changes in attitudes and behaviors of young people such as being upset after using the Internet or making adverse comments about friends or observing changes in their relationships with friends.

Fisher and Gonzalez (2013) suggest that contextual performance such as parents helping their children, teachers helping their students and employers helping their employees, is increasing in importance in today's social environments. Parents, teachers and employers not only have to deliver their social responsibilities but should also work together as a team to create social opportunities that foster responsible individual and group attitudes and behaviors that strengthen the cyber coping capabilities of young people. An essential tool to achieve these goals is the ability to influence and persuade others.

Bhat et al (2011) suggest that cyber bullying or bullying using information and communications technology becomes more and more widespread. The Asian region accounts for one of the highest regions in the world as far as mobile phone and Internet users are concerned. It appears that students in particular experience cyber bullying which in turn leads to several detrimental psychosocial effects that detract from their ability to be successful in school. In some instances, student suicides have been linked to cyber bullying goals. The outcome of their research suggests a number of ways of reducing cyber bullying and other harmful uses. This includes the sharing of knowledge about media literacy elements such as the definition of cyber bullying and behavioral examples of types of actions that constitute cyber bullying, knowledge and understanding of the types of ICT used to cyber bully, the roles in cyber bullying including that of active cyber bully, secondary cyber bully, observer and target, what actions each one can take to prevent cyber bullying and the specific actions students should take if they are cyber bullied. Some of these actions could be taking screen shots, printing evidence, speaking to trusted adults, not retaliating as this often escalates the cyber bullying and what the clear consequences are for those who engage in cyber bullying.

These initiatives are targeted at teachers and students as Bhat et al consider that students cannot achieve improvements on their own. Parents are a key element of media literacy initiatives. Parents provide and pay for computers, Internet connections, and cell phones and should acknowledge that it is a parental responsibility to teach children how to use these powerful forms of communication in an ethical and safe manner. Parents need to know and understand that with children who are minors, they can be held accountable for the actions of their children.

In contrast, Klick et al (2012) suggest, based on some research they conducted in the United States, that mobile technology has made a significant positive contribution to people's lives and they link mobile phone use to a historic drop in the crime rate and urges policymakers to encourage individuals to carry their cell phones with them as a way to 
further deter crime. Klick et al report a novel contributing factor to help explain the remarkable crime decline of the 1990s, when crime rates dropped by about a third across all crime categories. Mobile phones allow for quicker reporting of crimes and in some cases real time communication of details about the crime and the criminal. The perceived risk of apprehension could increase among motivated offenders when they notice potential targets are carrying a mobile phone. As technology has improved to allow the transmission of photographic images, identification, apprehension, prosecution and conviction all presumably become even more likely.

Jones and Mayo (2013) consider whether electronic media such as smart phones, iPods, computers and tablets are contributing to society's growing physical estrangement. Jones and Mayo argue that the reverse is true. People who use social media sites such as Facebook are also the most sociable people in real life. Social media actually creates more opportunities for meeting up. It allows people to be more spontaneous and creates more face to face socialization, not less. People prefer to belong to communities irrespective of whether these are online or physical such as the village shop or local Post Office. If people find value in social relationships, then being a member of a social media community such as Facebook ranks much higher provided that it reflects people's values and beliefs appropriately.

Table 1. Summary of Common Cyber bullying Methods (Source: Rogers, 2010)

\begin{tabular}{|c|c|}
\hline Cyber bullying Method & Details \\
\hline Text Messages & Takes the form of messages that are threatening, offensive or persistent \\
\hline $\begin{array}{l}\text { Picture/Video clip via } \\
\text { Mobile Phone Cameras }\end{array}$ & $\begin{array}{l}\text { Clear images are captured to make the victim feel threatened or embarrassed. } \\
\text { Random physical assaults are filmed and shared. }\end{array}$ \\
\hline Mobile Phone Calls & $\begin{array}{l}\text { Bullies bombard victims with silent or persistent calls and abusive messages or } \\
\text { steal the phone and harass others, causing the victim to appear responsible for the } \\
\text { call }\end{array}$ \\
\hline E-mails & $\begin{array}{l}\text { Multiple E-mail accounts make it easy to send threatening or bullying E-mails } \\
\text { using a pseudonym or somebody else's name }\end{array}$ \\
\hline Chat rooms & $\begin{array}{l}\text { Can be a good and safe way to communicate for young provided security measures } \\
\text { are in place. Can easily become a forum for menacing and targeting people }\end{array}$ \\
\hline Instant Messaging (IM) & $\begin{array}{l}\text { Once messages are posted, they are in "cyber land". Things can get out of hand } \\
\text { and can include groups of people ganging up on one target }\end{array}$ \\
\hline Social Networking Sites & $\begin{array}{l}\text { Can be misused without appropriate security settings. Easy to spread rumor and } \\
\text { gossip. Children often accept strangers as "friends" and give access to personal } \\
\text { information. It is possible to cyber target by posing as someone else. Bullies can } \\
\text { retain anonymity and stalk their victims }\end{array}$ \\
\hline Websites & $\begin{array}{l}\text { Bullies can set up defamatory blogs or create personal websites featuring their } \\
\text { victim. They can set up online polling sites asking an unlimited number of } \\
\text { questions about the victim }\end{array}$ \\
\hline
\end{tabular}




\subsubsection{Media Reports/Studies and Court Room Cases}

Media Reports/Studies:

Daniel Perry (17 years old): Sky News reports on 18 August 2013 that police are investigating claims that a teenage boy killed himself after being targeted by online blackmailers. He is thought to have fallen victim of to a scam where Internet users are lured into online chats and then blackmailed. It is believed that he thought he was talking to a girl of similar age in the US state of Illinois for several months through Skype and other websites. It appears that he killed himself on 15 July 2013 when he was told by the blackmailers that the conversations he had with the girl would be shared with his family and friends unless he paid up.

The Huffington Post reports on 18 August 2013 that Sergeant Jeremy Scott, a serving police officer who posted an offensive message online following Baroness Thatcher's death, has resigned. He is understood to have written on social networking website Twitter that he hoped that Baroness Thatcher's death was "painful and degrading". His resignation was accepted by Scotland Yard with immediate effect.

His resignation comes after figures from Scotland Yard revealed that three police officers have been sacked for misusing social media over the past five years. Allegations linked to the use of sites including Facebook and Twitter have been recorded against 75 Metropolitan police officers since 2009 , with 38 of the claims substantiated.

BBC West reported in July 2013 that Ben Townsend, 25 years old, received a fine of $£ 1000$ by a local court and a life time ban by Cheltenham Football Club for racially abusing two footballers on Twitter. The offence took place in May 2013 after a football match between Northampton Town FC and Cheltenham Town FC. Responses from other Twitter users alerted the police who tracked him down and arrested him.

Another offender, Swansea student Liam Stacey, was jailed in 2012 for making racist remarks about another footballer on a social media site. These examples should be tough lessons for the users of social media that the law still applies online. On 16 June 2013 Sky News reported that the first juror to be prosecuted for contempt of court using the Internet has been jailed after her online activities led to a retrial in a multi-million pound drugs case. Joanne Fraill was sentenced to 8 months prison.

\section{Court Room Cases:}

The researcher engaged in practical field research, by attending public hearings at a Swindon Magistrates Court over a prolonged period of time (October 2012 to August 2013), capturing extensive relevant research data to act as supportive evidence. The court cases listed below involved incidents of theft, fraud, domestic violence, drug dealing and grievous bodily harm $(\mathrm{GBH})$. The statistical analysis of the research sample suggests that more than $70 \%$ of court cases involve the misuse of mobile phones or social media networks. Of the actual cases where the misuse of mobile or social media technology was evident, approximately $55 \%$ of cases ended up in domestic violence or physical assaults. $45 \%$ of cases resulted in drug dealings/abuse and mental/physical threats (Table 2). 
Table 2. Statistical Analysis of Observed Court Cases/Trials October 2012 to August 2013

\begin{tabular}{|l|l|l|}
\hline Type of Case/Trial & Number of Cases/Trials & Percentage of Total Number \\
\hline Irrelevant: & & \\
\hline Traffic Violations & 15 & 10 \\
\hline Theft & 15 & 10 \\
\hline Fraud & 10 & 7 \\
\hline Total: Relevant: & 40 & $27 \%$ \\
\hline Domestic Violence & 30 & 20 \\
\hline GBH & 30 & 20 \\
\hline Drug Abuse/Dealing & 20 & 13 \\
\hline Threats & 30 & 20 \\
\hline Total: & 110 & $73 \%$ \\
\hline
\end{tabular}

1. Young man aged 24 years of age splits up with his girl friend. She continues to hassle him by sending text messages to his mobile. He cannot cope and decides to sleep in his car in a public car park. Consumed food and alcohol in the car and turned on the engine during the night to keep warm. A routine police patrol leads to his arrest for being drunk in charge of a motor vehicle. He loses his driving license for 12 months.

2. A young couple splits up. He meets her sometime later and takes her mobile phone to check text messages and detailed call records as he suspects that this all happened because of her new boy friend. He then sends threatening messages/makes threatening calls to her new boy friend. He was issued with a community order for 80 hours of community work.

3. A well-known drug dealer uses the Blackberry Messaging (BBM) facility on his mobile phone to discuss with his friends the details of a new drug delivery. He gets arrested during a routine check of his car (some drugs found) and the Police confiscate and analyze call and text details from his mobile phone which includes details of his 'conference calls' with his friends. The case in currently pending and will almost certainly lead to a custodial sentence for this drug dealer.

4. Young man relaxes at home and has some alcoholic drinks. Receives compromising text messages from his girl friend who thinks he is cheating on her. He wants to sort this out immediately and drives his car to see her but is stopped by Police for erratic driving and is convicted of drunk driving. He loses his license for 12 months.

5. Young man receives threatening text messages on his mobile. Replies go backwards and forwards, ultimately leading to a visit to the other person's home where the young man commits aggravated bodily harm. He is found guilty and a suspended custodial sentence is awarded plus 60 hours of unpaid community work. 


\subsection{Knowledge Gap}

The literature review from this current research has confirmed that there is a need to develop and train young people much more and using a different approach in the safe and appropriate use of mobile technology, such as texting and picture/video sending, and associated social media sites such as Facebook and Twitter. Established subject matter experts suggest that increasing awareness levels and providing guidelines for young people in how to use mobile technology and media sites are adequate activities to help young people stay safe in today's texting, twittering and social networking world. Reality appears to differ. Recent incidents (Section 1.2) suggest that the existing training and guidance that is provided to young people is not working effectively and that perhaps a different approach needs to be developed and implemented that closes this gap.

Young people who are emotionally disturbed and affected by, for example, adverse comments made about their appearance on a social media site, are unlikely to make good use of any social media site's help and support tool or ask parents or trusted friends for help and advice. They appear not to be in control of themselves anymore and this leads to irrational and uncontrolled responses to these cyber bullying attacks. The practical insights from solicitors and district judges from face to face meetings together with the suggested views of the researcher will help to close the knowledge gap.

\subsection{Main Research Questions/Hypotheses}

The main research questions for this research are:

1. How widespread is cyber bullying really? Are the effects as serious as is reported by the media?

2. What practical and workable solutions can be developed to improve and increase the e-safety of young people?

3. Does a potential shortcoming exist between the existing e-safety training and guidance that is provided by education authorities, parents and employers?

4. How can the contributions to knowledge from this research be practically applied to help young and mature people to cope better with incidents of cyber bullying or mobile technology abuse?

The following hypotheses were constructed:

H1: The increased use of mobile phones and its technology leads to higher/lower levels of criminal activities. There is a proportionate relationship between the use of mobile technology and social media and an increase in domestic violence/aggravated bodily harm (GBH)

H2: Mobile phone operators and providers of social media sites are discharging their social responsibilities of educating young people more in the safe use of the technologies and associated applications

H3: People are using mobile technology and social media as a substitute for face to face 
communications. This affects the ability to socialize and develop interpersonal relationships adversely

H4: Parents, teachers and employers are failing in their duty of care to take ownership of providing young people with practical advice that is fit for purpose for the intended audience. Incentive schemes could improve this situation

\section{Research Methodology}

\subsection{Method}

The researcher considered that a qualitative research approach was most appropriate for this research and therefore applied a constructivist interpretivist research approach within a phenomenological research paradigm. He considered that this was most appropriate and defendable in order to make a valid and reliable contribution to knowledge. In addition, some quantitative research approach was used to capture relevant statistical information from the court cases and to strengthen the resulting conclusions drawn from this evidence. The outcome of this research is applicable to both academics and practitioners. The aim and purpose of this research is to suggest new practical approaches to combat cyber bullying and misuse of mobile technology amongst primarily young people and how these should be applied to make them work effectively. As such, it is important that, for example, parents and teachers experience the new approaches themselves to confirm that these are valid and reliable. The researcher suggests that an increase in the use and abuse of mobile technology and associated social media sites (Section 1.1) has necessitated the need for this research and to propose more effective solutions to develop e-safety in young people. Two solicitors from a local law firm in Swindon and twelve district judges and other solicitors from the Swindon Magistrates Court were interviewed by the researcher during face to face and ad hoc interviews. The interviews were conducted between October 2012 and August 2013 and recorded verbatim to ensure that all responses were captured correctly, including meaning as intended. Interviews were semi-structured. Participants' ages ranged from 35 years to 55 years and they had between ten and thirty years of practical work experience. The participants were asked what their experiences were with cyber bullying and misuse of mobile technology in court cases and to provide appropriate details to support their statements subject to data protection limitations. The researcher then focused his attention on capturing what the participants considered to be the main applications of cyber bullying and misuse of mobile technology and what the participants considered to be practical approaches to mitigate or eliminate the effects of these phenomena on young people.

\subsection{Data Collection, Interpretation and Triangulation}

The researcher considered three methods to collect relevant research data to answer the main research questions and hypotheses from Section 1.4: a review of the literature, relevant media reports/studies, court room cases (Section 1.2) and face to face interviews (Section 3.1), within the context of a phenomenological research paradigm and an associated constructivist interpretivist research approach. The researcher, in his role as participant observer, added his contributions of what he considers are practical and effective means to reduce or eliminate the 
effects cyber bullying attacks have on young people in order to obtain different perceptions of the phenomena under investigation. Data was collected over different time frames and from different sources.

The researcher applied triangulation as a means to use a combination of different methods in order to reduce reliance on a single method.

\section{Results}

\subsection{Face to Face Interviews}

Two local solicitors from a local law firm were interviewed by the researcher to collect further evidence and to capture the insights of the solicitors based on their practical experiences as law practitioners. In addition, twelve ad hoc and planned interviews took place before and after actual court hearings with district judges and other solicitors at Swindon Magistrates Court. These short interviews typically lasted 30 minutes. The purpose of these interviews was to gather additional relevant and reliable information from law practitioners. The research materials used were a semi-structured questionnaire with open-ended questions for the face to face interviews. Further open-ended questions were used during these semi-structured meetings to elicit further data from the participants, for use in the triangulation of the collected data. The participants in the research were given details of the purpose of the research. The researcher asked all participants to give open and honest answers that were based on, for example, what the participants had actually done and how they had done it. Where participants strayed from this path, the researcher quickly pulled interviewees back onto the right track. The planned interview lasted around three hours. All interviews took place in appropriate meeting room surroundings to put the participants at ease and to create a relaxed atmosphere that aided a genuine participation. The law practice solicitors (Rob and Chris) considered that mobile technology is increasingly being misused by drug dealers to target their existing and potential new audiences via applications such as texting, Blackberry Messaging (BBM) and social media such as Twitter and Facebook. The number of court cases where defendants are convicted of crimes due to the misuse of mobile technology and social media is on the increase. People's phone numbers, their names and other personal details such as home address are often quoted in these types of communications which are then easy to obtain by the Police and the Courts. Police now have access to much improved technology that allows for faster and more accurate retrieval of appropriate data that can then be used in the Court Room, for example, to convict the guilty party or parties very effectively. Forensic Telecommunications Services (FTS) in the UK can retrieve data and images from any mobile device up to 12 months since the data and images have been deleted and provide the Police with detailed accounts which are admissible as evidence in court. Rob and Chris reported that iphones are increasingly used to show inappropriate material to very young children. Predators encourage young girls on Skype to commit to do inappropriate sexual activities. The number of offenders in this respect is on the increase and Rob and Chris have recently been engaged in a larger number of cases than, for example, compared to 5 years ago. It is suggested that most young people between the ages of 14 and 24 live their lives through the use of mobile technology and social media. Mobile technology and social media have been seen to be the catalyst of new crimes. Rob and Chris 
suggest that young people need to be educated much earlier (Age 8 onwards) in the appropriate use of mobile technology and social media.

The interviewed district judges and other solicitors suggest that there has been a substantial increase in court cases in the United Kingdom where incidents of aggravated and grievous bodily harm are directly attributable to the incorrect/misuse of mobile technology or social media sites.

This includes text messaging, phone calls and sites such as Facebook and Twitter. The police are providing increasing levels of evidence such as details of SMSs and MMSs. They consider that this situation is becoming epidemic, judging by the number of cases involved. They suggest that this could be as high as $2 / 3$ of all court cases. As technology improves further, new opportunities will open up for criminals and cyber bullies to look for new ways of making this work for their intended purposes. Cyberspace and Satellite services will enhance the availability of what has been communicated and when, by whom and how. This issue is live and it is necessary to take proactive action to provide much stronger and relevant help and support to young people (Table 3). They suggest that young people aged 8 years of age and over need to be educated in a number of ways such as age dependant training films, posters in schools, colleges and Universities and regular class room sessions with practical exercises that address both the bullied and the bully so that young people can see both perspectives. They consider that mobile phone operators and owners of social media sites also need to take more proactive social responsibilities by developing positive attitudes and solutions to reduce cyber bullying and mobile phone misuse substantially.

Table 3. How to Improve E-Safety-Application and Ranking of the Considered Solutions

\begin{tabular}{|c|c|c|}
\hline Skills & Application & Ranking \\
\hline \multirow{3}{*}{$\begin{array}{l}\text { Building } \\
\text { Self-Confidence } \\
\text { and becoming } \\
\text { "Cyber Coping" }\end{array}$} & $\begin{array}{l}\text { Developing an ability to say "No" and ignoring acts } \\
\text { of cyber bullying will develop higher levels of } \\
\text { self-confidence in emotionally unstable youngsters }\end{array}$ & $\begin{array}{l}\text { Considered important by the } \\
\text { literature review and face to face } \\
\text { interviews }\end{array}$ \\
\hline & $\begin{array}{l}\text { There is a relationship between the attitude people } \\
\text { hold towards what others stand for and how they } \\
\text { respect them. People must not be used as a means to } \\
\text { an end. All communications must be genuine and } \\
\text { authentic. Showing empathy and sincerity are the } \\
\text { building blocks of authentic interpersonal } \\
\text { relationships }\end{array}$ & $\begin{array}{l}\text { Considered by all parties to be } \\
\text { highly important. Young people } \\
\text { who develop the right attitude } \\
\text { will be less likely to engage in } \\
\text { cyber bullying and mobile } \\
\text { misuse activities * }\end{array}$ \\
\hline & $\begin{array}{l}\text { Young people need to learn not to copy others who do } \\
\text { engage in undesirable activities such as cyber } \\
\text { bullying by following their own values and beliefs of } \\
\text { what is right and wrong and what is acceptable and } \\
\text { unacceptable behavior towards others }\end{array}$ & $\begin{array}{l}\text { Considered important by the } \\
\text { literature review and the face to } \\
\text { face interviews. Young people } \\
\text { should not follow the "herd } \\
\text { instinct" but decide for } \\
\text { themselves by considering, for }\end{array}$ \\
\hline
\end{tabular}




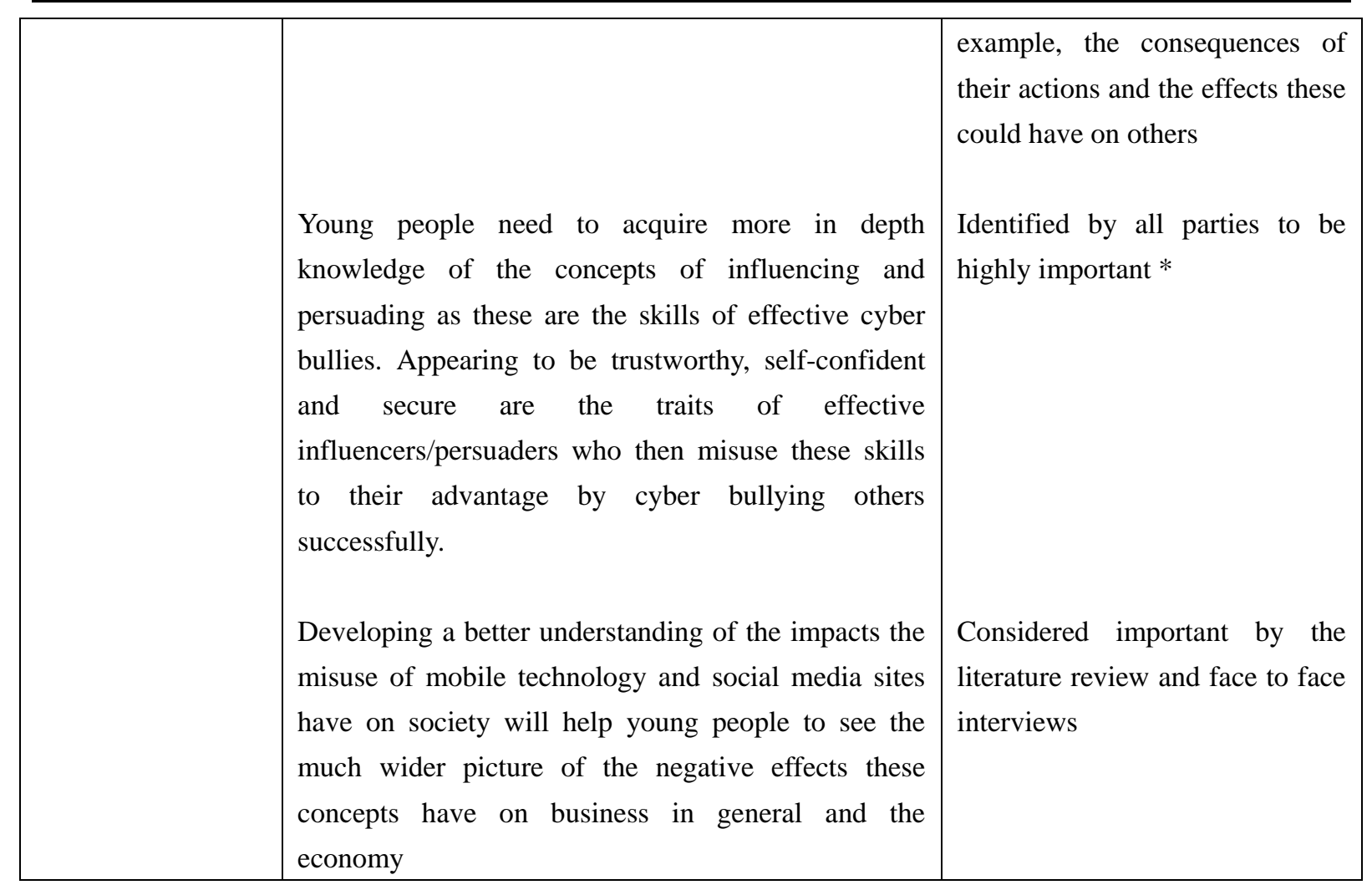

*Literature review, face to face interviews and media reports/studies

\section{Discussion}

The evidence from the literature review, face to face meetings with law professionals, media reports and actual court room cases suggests that there is a link between the increasing use of mobile technology and social media websites and increased levels of associated crimes. This is not limited to committing crimes that affect the other person(s). Recent suicide cases such as Hannah Smith (2013, aged 14) and Daniel Perry (2013, aged 17) suggest that young people are not sufficiently informed and trained how to deal and cope with the social pressures they are placed under by cyber bullies such as threatening behaviors and malicious rumors. They may not be aware of and appreciate the consequences the various forms of cyber bullying can have on the lives of other people, irrespective of the victim's age. Older people can be emotionally unstable or uninformed and fall victim to cyber bullying, too. There is no panacea for all-round success to stop cyber bullying and the misuse of mobile technology and social media sites but it is important to take more proactive actions to alleviate the problem as much as is practically and realistically possible. Actions speak louder than words and it is the responsibility of parents, teachers, employers and mobile services operators/owners of social media sites to increase the e-safety of young people. E-safety needs to start at home. Parents need to spend more quality time with their children to explain the various forms of cyber bullying in detail. They should then use real life examples to show their children what it feels like to be cyber bullied by another person and what the consequences are. Young people need to experience what it "feels like" to be cyber bullied. 
Parents need to encourage their children (aged 8 and above) to report and talk about cases of cyber bullying and incentivize them to do so willingly. They need to change their children's attitude to feel good about the reporting of incidents and reward this behavior with gifts appropriate to the age of the young person. Young people should adopt that asking for help is considered to be a strength and not a weakness. This whole approach could achieve desired repeat behaviors and have a knock-on effect on other parents and their children. Teachers need to work closely with parents to ensure that there is a consistent and co-operative approach between them (one version of the truth) and that young people are getting the message that cyber bullying is unacceptable. Teachers could set up focus groups that address cyber bullying and the misuse of mobile technology and then share the work of these groups during school assembly, on specifically designed posters that appeal to young people and by sending out regular "Cyber Coping" bulletins. Mobile phone operators and owners of social media sites need to provide more practical advice to users such as what forms of misuse exist, what the effects are on the victims and what the legal implications are for those who cyber bully others. Cyber bullying can affect how people perform at work and directly affect a company's reputation which in turn can lead to loss of business, customers and profit. Employers should make it clear to employees that cyber bullying is not an acceptable behavior and that proven cases will lead to dismissal and/or prosecution. Help should be offered to employees who are victims of cyber bullying through professional coaching services. Human Resources (HR) need to ensure that this is reflected in company HR policies. The four hypotheses of this research are supported by strength of evidence from the literature review, face to face interviews, media reports/studies and court room cases (see Table 4 for a summary of the results), namely:

H1: The increased use of mobile phones and its technology leads to higher/lower levels of criminal activities. There is a proportionate relationship between the use of mobile technology and social media and an increase in domestic violence/aggravated bodily harm (GBH). This premise holds true. Although some evidence suggests that the wider availability of mobile phones has made some contribution towards reducing potential crimes, mobile phone misuse and social media abuse crime rates in the United Kingdom have increased in recent years. This includes cases of domestic violence and GBH

$\mathrm{H} 2$ : Mobile phone operators and providers of social media sites are discharging their social responsibilities of educating young people more in the safe use of the technologies and associated applications. This hypothesis is valid. There is sufficient evidence from the outcomes of this research that suggests that mobile phone operators and owners of social media sites are not committed to engage in devising and implementing e-safety improvement programs for young people

H3: People are using mobile technology and social media as a substitute for face to face communications. This affects the ability to socialize and develop interpersonal relationships adversely. This is a valid hypothesis. Young people are spending more of their time on the phone and using social media sites to communicate with each other.

It appears that face to face communications are no longer the preferred method of 
communicating with each other

H4: Parents, teachers and employers are failing in their duty of care to take ownership of providing young people with practical advice that is fit for purpose for the intended audience. Incentive schemes could improve this situation. This premise holds true.

These groups are not sufficiently engaged in proving young people with appropriate practical advice and support to cope with incidents of cyber bullying and mobile technology better and more effectively. Awards and incentivized schemes to achieve good repeat behaviors would make a major contribution to improve the identified shortfall

Table 4. Hypotheses and Research Questions: Summary of Results

\begin{tabular}{|c|c|c|}
\hline Hypothesis & Related Research Question(s) & Results \\
\hline $\begin{array}{l}\text { H1: The increased use of mobile } \\
\text { phones and its technology leads to } \\
\text { higher/lower levels of criminal } \\
\text { activities. There is a proportionate } \\
\text { relationship between the use of } \\
\text { mobile technology and social } \\
\text { media and an increase in domestic } \\
\text { violence/aggravated bodily harm } \\
(\mathrm{GBH})\end{array}$ & $\begin{array}{l}\text { 1. How widespread is cyber } \\
\text { bullying really? Are the effects as } \\
\text { serious as is reported by the } \\
\text { media? } \\
\text { 2. What practical and workable } \\
\text { solutions can be developed to } \\
\text { improve and increase the e-safety } \\
\text { of young people? }\end{array}$ & $\begin{array}{l}\text { The evaluation of the literature was } \\
\text { positive but not conclusive to } \\
\text { determine what needs to be done } \\
\text { practically. The face to face } \\
\text { interviews and media reports } \\
\text { concluded that parents, teachers and } \\
\text { employers need to focus their efforts } \\
\text { more on those identified as being } \\
\text { vulnerable whilst at the same time } \\
\text { provide in depth coaching for the } \\
\text { wider community }\end{array}$ \\
\hline $\begin{array}{l}\mathrm{H} 2 \text { : Mobile phone operators and } \\
\text { providers of social media sites are } \\
\text { discharging their social } \\
\text { responsibilities of educating } \\
\text { young people more in the safe use } \\
\text { of the technologies and associated } \\
\text { applications }\end{array}$ & $\begin{array}{l}\text { 3. Does a potential short coming } \\
\text { exist between the existing } \\
\text { e-safety training and guidance } \\
\text { that is provided by education } \\
\text { authorities, parents and } \\
\text { employers? } \\
\text { 4. How can the contributions to } \\
\text { knowledge from this research be } \\
\text { practically applied to help young } \\
\text { and mature people to cope better } \\
\text { with incidents of cyber bullying } \\
\text { or mobile technology abuse? }\end{array}$ & $\begin{array}{l}\text { The literature was not positively } \\
\text { conclusive and did not provide } \\
\text { sufficient valid and reliable evidence } \\
\text { that suggests that this is the case. } \\
\text { Inputs from the face to face } \\
\text { interviews and court cases suggest } \\
\text { that the providers of such services } \\
\text { are not seen to be engaging in } \\
\text { activities that lead to a reduction in } \\
\text { cyber bullying and mobile phone } \\
\text { misuse }\end{array}$ \\
\hline $\begin{array}{l}\text { H3: People are using mobile } \\
\text { technology and social media as a } \\
\text { substitute for face to face } \\
\text { communications. This affects the } \\
\text { ability to socialize and develop } \\
\text { interpersonal relationships } \\
\text { adversely }\end{array}$ & $\begin{array}{l}\text { 2. What practical and workable } \\
\text { solutions can be developed to } \\
\text { improve and increase the e-safety } \\
\text { of young people? } \\
\text { 4. How can the contributions to } \\
\text { knowledge from this research be } \\
\text { practically applied to help young }\end{array}$ & $\begin{array}{l}\text { The literature is positively } \\
\text { conclusive that young people in } \\
\text { particular are not communicating } \\
\text { directly with each other anymore. } \\
\text { This has been supported by evidence } \\
\text { from the court room cases and } \\
\text { reports/studies by the media. }\end{array}$ \\
\hline
\end{tabular}




\begin{tabular}{|c|c|c|}
\hline & $\begin{array}{l}\text { and mature people to cope better } \\
\text { with incidents of cyber bullying } \\
\text { or mobile technology abuse? }\end{array}$ & \\
\hline $\begin{array}{l}\text { H4: Parents, teachers and } \\
\text { employers are failing in their duty } \\
\text { of care to take ownership of } \\
\text { providing young people with } \\
\text { practical advice that is fit for } \\
\text { purpose for the intended audience. } \\
\text { Incentive schemes could improve } \\
\text { this situation }\end{array}$ & $\begin{array}{l}\text { 2. What practical and workable } \\
\text { solutions can be developed to } \\
\text { improve and increase the e-safety } \\
\text { of young people? } \\
\text { 3. Does a potential shortcoming } \\
\text { exist between the existing } \\
\text { e-safety training and guidance } \\
\text { that is provided by education } \\
\text { authorities, parents and } \\
\text { employers? }\end{array}$ & $\begin{array}{l}\text { The evaluation of the literature was } \\
\text { positive but not conclusive. The face } \\
\text { to face interviews and inputs from } \\
\text { the media studies/reports and court } \\
\text { room cases suggest that these groups } \\
\text { do not focus their attention and are } \\
\text { not sufficiently engaged and } \\
\text { committed to reduce or eliminate } \\
\text { cyber bullying and mobile phone } \\
\text { abuse amongst people of all ages } \\
\text { (but particularly the young and } \\
\text { inexperienced) }\end{array}$ \\
\hline
\end{tabular}

\section{Conclusions}

The technological revolution has changed people's lives forever and irreversibly. With the considered right to have access to and being able to use this technology when and where people want, come social responsibilities. Digital communication has grown much faster than people of all ages have been able to catch up with. Technology is increasingly misused to threaten, harass and embarrass victims and methods known as cyber bullying have become more sophisticated and widespread. By working in partnership and driving each other to succeed, parents, teachers, employers and mobile phone operators/owners of social media sites can reduce and alleviate risks of misuse, promote responsibilities and foster positive attitudes and behaviors in younger and more mature people. Young people have a very short attention span so it will be important to concentrate efforts where the greatest achievements can be realized in the shortest period of time. It is encouraging that the Office for Standards and Education and Children's Services and Skills (Ofsted) in the United Kingdom has included e-safety and cyber bullying as part of school inspection criteria since June 2012. No empirical data is available yet that could provide evidence of how successful this initiative has been at the end of its first year. Combating the misuse of mobile technology and social media sites is a long journey and many steps need to be taken to complete it. The research was limited to a relatively small number of district judges and solicitors from the Magistrates Court in Swindon. Insights and subject matter knowledge from a larger sample of law professionals would have provided richer and diverse research data to address the research scope in more depth and universally. Further research should be conducted to assess and confirm the actual cost to the economy of the effects of cyber bullying such as loss of income to employers, employing more counselors in educational establishments and the need for additional law professionals. It is confirmed that the research scope from Section 1.4 has been answered and that all four hypotheses hold true and are valid in the context of this research. 


\section{References}

Becta. (2012). About the Department, London: Becta, www.education.gov.uk/aboutdfe/armslengthbodies/900192537becta

Belsey, B. (2004). Cyberbullying Definitions, Canada: Cyberbullying Canada, www.cyberbullying.ca

Center, www.pewInternet.org/Reports/2010/Social-Media-and-Young-Adults.aspx

De Angelis, T. (2000). Is Internet addiction real?, Monitor on Psychology, 31(4), 24-26

Fisher, E. J. P., \& Santana Gonzalez, Y. (2013, b). The Art of Influencing: How Managers Can Put 'Squar Pegs' into 'Round Holes', Journal of Management Research, 5(4), 1-19, Macrothink Institute, http://dx.doi.org/10.5296/jmr.v5i4.3971,

Giant, N. (2013). E-Safety For The i-Generation-Combating The Misuse and Abuse Of Technology In Schools, Jessica Kingsley Publishers

Goldberg, I. (1996). Internet Addiction Disorder, New Jersey: Rider University, http://users.rider.edu/ ruler/psycyber/supportgp.html

Greenfield, D. (1999). Virtual Addiction: Help for Netheads, Cyber Freaks and Those Who Love Them, Oakland, CA: New Harbinger Publications

Hinduja, S., \& Patchin, J. W. (2009). Bullying Beyond the Schoolyard: Preventing and Responding to Cyberbullying, Thousand Oaks, CA: Sage Publications

Intersperience Research Limited (2012). I am My Smartphone, Cumbria, UK: Intersperience,

Jones, G., \& Mayo, E.(2013). What future community?, benhealth magazine, Issue 24, pp.6-7, Autumn Edition, Benenden Healthcare Society

Klick, J.; MacDonald, J., \& Stratmann,T. (2012). Mobile Phones and Crime Deterrence: An Underappreciated Link, Research Handbook on the Economies of Criminal Law, Alon Harel and Keith N Hylton, eds.,IJ of Penn, Inst. Ofr Law and Econ Research Paper No 12-33

Lenhart, A. (2007). A Timeline of Teens and Technology, Washington, D.C.: Pew Internet and American

Life, http://www.pewInternet.org/Presentations/2007/A-Timeline-of-Teens-and-Technology.aspx

Ofcom. (2010). UK Children's Media Literacy, London, Ofcom, http://stakeholders.ofcom.org.UK/binaries/research/media-literacy/ukchildrensm11.pdf

Ofcom. (2011). A Nation Addicted to Smartphones, London: Ofcom, http://media.ofcom.org.uk/2011/08/04/a-nation-addicted-to-smartphones

Ofsted. (2012). Handbook for Inspecting Schools in England under Section 5 of the Education Act 2005 (as amended) from September 2012, London: Ofsted

Pew Research Center. (2010). Social Media and Young Adults, Washington, D.C: Pew Research 


\section{Macrothink}

Business and Economic Research

ISSN 2162-4860 2013, Vol. 3, No. 2

Rogers,V. (2010). Cyber Bullying-Activities To Help Children And Teens To Stay Safe In A Texting, Twittering, Social Networking World, Jessica Kingsley Publishers

Smith, P., Mahdawi, J., Carvalho, M., Fischer, S., Russell, S., \& Tippett, N. (2008). Cyberbullying: Its nature and impact in secondary school pupils, Journal of Child Psychology and Psychiatry, 49, 4, 376-385, http://dx.doi.org/10.1111/j.1469-7610.2007.01846.x

Willard, N. (2007). Cybersafe Kids, Cyber-savvy Kids: Helping Young People Learn to Use the Internet Safely and Responsibly, San Francisco: CA: Jossey-Bass.

www.intersperience.com/article_more.asp?art_id=43

Young, K. S. (1998). Caught in the Net: How to Recognize the Signs of Internet Addiction-and a Winning Strategy, New York: John Wiley and Sons.

\section{Copyright Disclaimer}

Copyright reserved by the author(s).

This article is an open-access article distributed under the terms and conditions of the Creative Commons Attribution license (http://creativecommons.org/licenses/by/3.0/). 